How to Cite

Arjawa, A. G. P., Sariyasa, -, \& Suweken, G. (2018). Developing instructional multimedia for teaching line and angle to the seventh grade students of junior high school. International Journal of Engineering \& Computer Science, 1(1), 6-13.

https://doi.org/10.31295/ijecs.v1n1.18

\title{
Developing Instructional Multimedia for Teaching Line and Angle to The Seventh Grade Students of Junior High School
}

\author{
A.A Gd Putra Arjawa \\ Ganesha University of Education, Singaraja, Indonesia \\ Corresponding author email: arjawa78@gmail.com \\ Sariyasa \\ Ganesha University of Education, Singaraja, Indonesia \\ Gede Suweken \\ Ganesha University of Education, Singaraja, Indonesia
}

\begin{abstract}
This study was aimed at : (1) developing an instructional multimedia design for teaching line and angle to the seventh grade students of junior high school; (2) describing the result of the implementation of the multimedia using GeoGebra as media of exploration, Camtasia Studio as an application for sound and video editing, Lectora Inspire as the application for making layout and quiz;(3) finding out the validity of the multimedia for teaching line and angle to the seventh grade students of junior high school. The study used DDD-E model that consists of deciding, design, develop, and evaluate stages. The product was tried out in several stages which were done by instructional materials experts, and students at different schools and used qualitative and descriptive quantitative data analysis techniques. The result showed that the multimedia for teaching line and angle could be accepted as instructional media with the average score of 43.5 from the instructional material experts falling into valid criterion, and the mean score given by the material experts was 17 falling into valid criterion. The multimedia that has been developed also got a very good response from the students with the average score of 47.63. Based on the result that has been obtained, the multimedia that has been developed as a good qualification and is good for use in the process of teaching the topics of line and angle.
\end{abstract}

Keywords: DDDE, instructional media, line and angle, multimedia, teaching aid.

\section{Introduction}

The rapid development of the technology today makes it easy for someone to access information that he or she needs. This does not exclude educational world in which teacher and student can easily access or search teaching materials, references, or just share teaching materials by uploading them to the file. The ease that is caused by the development of technology would be better if it could be combined with the teacher's knowledge in providing or combining materials to support student learning. Of course, this will have a positive impact on the students' achievement, academically and non-academically.

In the Regulation of National Minister of Education No. 16 of 2007 on Academic Qualification Standard and Teacher Competence is stated that a teacher is required to possess competence in 1) using Information and Communication Technology for instruction, and 2) using ICT for developing him/herself. An example of the ICT which can be used to support instruction is a computer. The teacher can use a computer to access learning resources and then present the materials in an ICT-based instructional media.

The instruction that uses a computer is known as Computer Assisted Instruction (CAI). "In the concept of CAI, the computer is used as presenter of instruction, saver of instructional materials and analyst of instructional assessment" (Musfiqon, 2012). One form of the implementation of CAI is the use of computer-based instructional 
multimedia. It is not uncommon for the teacher to forget the importance of media in instruction, this causes instruction especially mathematical instruction to become less attractive to most students. As the consequence, mathematics has not undergone a significant improvement (Sri Rejeki, 2012).

In the effort to produce a good quality instruction, there are some aspects which contribute, among other things: instructional technique, use of interesting and varied instructional methods, student behavior, conducive learning condition and use of innovative instructional media. Instructional media is an element which plays an important role in instruction, besides the method used in instruction. Both elements are interrelated, like in instructional method selection, and, of course, will have an effect the type of instructional media that will be used. Although there are also some other aspects that need to be taken into account.

Hamalik (in Arsyad, 2005), states that "the use of media in instruction can increase motivation and stimulation in learning and even can bring psychological effects on the students." Based on this, a student will be helped very much with the presence of instructional media which can direct them in finding learning concepts, especially in mathematics instruction at school. The use of instructional media will develop student curiosity, which will influence the students' participation in following the lesson, such a situation will make it easy for the teacher to teach the materials to the students.

The students of junior high school still need media in learning. This is based on their cognitive ability which is still at the concrete operational stage. Besides, they also find it difficult to learn mathematics because the materials are abstract and difficult to imagine.

Based on the result of an interview with some mathematics teachers, teachers have used instructional media such as slideshow which was developed using Power-Point. However, they only presented the materials in the form of pictures and texts, without any student contribution. This caused the instruction to focus on the teacher and minimal student activity in learning. While the current curriculum requires the use of student-centered learning and the students to be active in constructing their own knowledge.

The use of slideshow media which only presents texts and pictures often causes it difficult for some students to imagine the definition of a line, line ray, or other topics related to line and angle topics, which hinders them in solving problems related to everyday life. Beside using media in the form of a slideshow, visual aids were also used in teaching Geometry. However, if it is analyzed in depth, the visual aids have a limited function, and the cost of their procurement and storage is high enough.

Along with the development of ICT, an instructional media is often used in combination with other media, this is caused by the difference in learning style among students. With the difference the use of varied media will make it efficient to teach, this agrees with Mustiqon's opinion (Mustiqon, 2012) that "Teacher can combine visual-based media, audio-based media, and kinesthetic-based media to present instructional materials in order all materials can be absorbed by all students although they have different learning styles".

The combination of some media to support learning process is called multimedia, Rayandra (212-45) states that "Multimedia is computer-based media which uses various types of media which are integrated into an activity." Compared to instructional media, the use of multimedia in instruction will be able to reach students' various learning styles.

The use of multimedia in instruction can be implemented in various subjects at school, not excluding mathematics. In teaching mathematics, instructional multimedia which integrates recording, pictures, music, and animation can give an interesting learning experience to the students. In addition, abstract instructional materials can be simplified through visualization in multimedia, with the help of a certain software. GeoGebra, Mathematica, and Maple are some software that can be used in developing instructional media, the media that are combined with other media developing software, such as Lecture Inspire, Power-Point or other software to produce an instructional multimedia for mathematics.

The use of instructional multimedia for line and angle topics is good for creating a more student-centered condition for the students compared to visual aids and slideshow designed by the teachers. Instructional media can display a visualization of the concepts of line and angle which tend to be less able to be imagined by the students. In addition, multimedia can also present a video recording which contains the implementation of angle and line concepts in the students' everyday situation.

Multimedia can also be inserted with a certain type of music or narrative. In addition, an assessment test which aims to measure the students' understanding of the topics of line and angle can be inserted into multimedia, and the result of this test can be directly known by the students at the end of the completion of the test. Since this multimedia is ICT-based, it can be stored in a flash disk or CD (Compact Disk). Easiness of access and the presence of assessment test in the instructional multimedia make it a very good facility for individual learning.

With the many media combined in multimedia, it is much better than other instructional media, and this is related to its more complex function and its capacity to contain various topics. Based on this result instructional multimedia 
that contains elements of the picture, sound, animation, video, and explorative media, of course, will engage many senses of perception of the students and will increase their memory power. This is similar to what is stated by Susanto (2008) that "there is a research about memory power that shows that on average we remember $20 \%$ of what we read; $30 \%$ of what we heard; $40 \%$ of what we saw; $50 \%$ of what we said; $60 \%$ of what we did; and $90 \%$ of what we read, heard, saw,said, and did.

Based on the explanation above, this study was aimed at : (1) developing an instructional multimedia design for teaching line and angle to the seventh grade students of junior high school; (2) describing the result of the implementation of the multimedia using GeoGebra as media of exploration, Camtasia Studio as an application for sound and video editing, Lectora Inspire as the application for making layout and quiz;(3) finding out the validity of the multimedia for teaching line and angle to the seventh grade students of junior high school.

\section{Research Method}

This was a development research. It used DDD-E that consists of four main stages,i.e. decide, design, develop, and evaluate. This study produced a multimedia for teaching line and angle topics that have been evaluated by experts and through a trial. In general, the stages of development of the output that is expected are presented in Table 1 below.

Table 1

Stages of Activities in Developing and Output Expected

\begin{tabular}{|c|c|c|}
\hline Stages & Description of Activities & Output and Achievement Indicators \\
\hline \multirow[t]{2}{*}{ Decide } & Identifying problems faced & $\begin{array}{l}\text { Problems in teaching mathematics for } \\
\text { line and angle topics have been } \\
\text { identified. }\end{array}$ \\
\hline & Analyzing the curriculum & $\begin{array}{l}\text { The scope of line and angle topics to be } \\
\text { developed has been known }\end{array}$ \\
\hline Design & $\begin{array}{l}\text { Designing multimedia for } \\
\text { teaching line and angle topics to } \\
\text { the } 7^{\text {th }} \text {-grade students of the } \\
\text { junior high school. }\end{array}$ & $\begin{array}{l}\text { The design of the multimedia for } \\
\text { teaching line and angle topics has been } \\
\text { developed }\end{array}$ \\
\hline \multirow[t]{3}{*}{ Develop } & $\begin{array}{l}\text { Implementing the design for } \\
\text { teaching line and angle to the } \\
7^{\text {th }} \text {-grade students of the junior } \\
\text { high school }\end{array}$ & $\begin{array}{l}\text { The multimedia for teaching line and } \\
\text { angle topics to the } 7^{\text {th }} \text {-grade students } \\
\text { has been developed }\end{array}$ \\
\hline & Doing a limited trial & $\begin{array}{l}\text { The data about the validity of the } \\
\text { multimedia for teaching line and angle } \\
\text { topics to the } 7^{\text {th }} \text {-grade students of the } \\
\text { junior high school have been collected } \\
\text { The multimedia for teaching }\end{array}$ \\
\hline & $\begin{array}{l}\text { Revising the product by using } \\
\text { the limited trial result }\end{array}$ & $\begin{array}{l}\text { that has been revised based on the } \\
\text { result of the limited trial and has met } \\
\text { the validity criteria has been produced. }\end{array}$ \\
\hline Evaluate & $\begin{array}{l}\text { Doing an evaluation at each } \\
\text { stage of the development of } \\
\text { multimedia for teaching line and } \\
\text { angle to the } 7^{\text {th }} \text {-grade students } \\
\text { of the junior high school }\end{array}$ & $\begin{array}{l}\text { Inputs and suggestions for the } \\
\text { multimedia for teaching line and angle } \\
\text { topics to the } 7 \text { th-grade students of the } \\
\text { junior high school have been obtained }\end{array}$ \\
\hline
\end{tabular}

Material Expert validation questionnaire, Instructional material expert validation questionnaire and student response questionnaire were the instruments used in this development research. The indicators of evaluation in the student response questionnaire used five scales of evaluation,i.e., strongly agree (score 5), agree (score 4), undecided (score 3 ), disagree (score 2), and strongly disagree (score 1). While in the material expert questionnaire and instructional material expert questionnaire there are three scales, i.e., valid (score 3), valid enough (score 2), and not valid (score 
1). All the instruments used in this research have been validated by two validators, i.e., two lecturers from Mathematics Education Department of Ganesha University of Education in terms of their contents.

The validation of the multimedia developed in this research was determined by the results of six experts, i.e., two mathematics teachers at SMP Negeri 2 Blahbatuh, two mathematics teachers at SMP Negeri 2 Gianyar, and a lecturers at Department of Mathematics Education and a lecture at Department of Chemistry Education, the Ganesha University of Education as experts to validate the multimedia developed, the evaluation was made by giving scores through questionnaire. The student response to the multimedia developed was also measured, this was done to find out whether the media being developed has met the students' needs and has helped them in learning.

The process of validation of the multimedia was done in two stages at different schools. The first validation stage was done by instructional material experts, material experts, Then the second stage was done by material experts. Students were given the questionnaire to see the usability of the multimedia, the student is involved are from SMP N 2 Blahbatuh and SMP N 2 Gianyar.

The data analysis was done by using qualitative and descriptive quantitative data analysis techniques. The qualitative data analysis technique was used to process data from the review by material experts, instructional material experts, and student response to the instructional multimedia. The result was then used as the guide or reference in revising the multimedia developed. The descriptive qualitative data analysis was used to process data from validation questionnaire, and student response questionnaire. This data analysis result was then used to find out the validity of the instructional multimedia developed and to find out whether it has met the students' needs in learning.

The validity of the multimedia developed can be found from the result of the validation by the experts by using questionnaires. The steps were as followed: (1) computing the ideal average score $(x)$ and Standard Deviation (SD) based on the guide for evaluating validity by instructional material experts and material experts; (2) converting total average score $(\bar{x})$ from instructional material experts and material experts into quthe alitative score with three scales by using Table 2 below.

Table 2

Conversion Table for the Validity of Instructional Multimedia instructional Material Experts and material experts

\begin{tabular}{llll}
\hline Interval & $\begin{array}{l}\text { Instructional Material } \\
\text { Experts' Interval }\end{array}$ & Material Expert Interval & Criteria \\
\hline$X_{\mathrm{i}}+\mathrm{SD}_{\mathrm{i}}<\bar{x}$ & $37.33<\bar{x}$ & $14.00<\bar{x}$ & Valid \\
$X_{\mathrm{i}}-\mathrm{SD}_{\mathrm{i}}<\bar{x} \leq X_{\mathrm{i}}+\mathrm{SD}_{\mathrm{i}}$ & $26.67<\bar{x} \leq 37.33$ & $10.00<\bar{x} 14.00$ & Valid Enough \\
$\bar{x} \leq X_{\mathrm{i}}-\mathrm{SD}_{\mathrm{i}}$ & $\bar{x} \leq 26.67$ & $\bar{x} \leq 19.00$ & Not Valid \\
\hline
\end{tabular}

Whether the multimedia developed has helped the students in learning or not can be found out by looking at the result of students' evaluation through the response questionnaire. The steps are as follows: (1) computing ideal average $(x)$ and ideal Standard Deviation (SD) according to the guide about the use of multimedia by the students; (2) converting total score average $(\overline{\boldsymbol{x}})$ from the students into qualitative sore with five scales by using Table 3 as shown below.

Table 3

Conversion Table for the Use of Instructional Multimedia by the Students

\begin{tabular}{lll}
\hline Interval & $\begin{array}{l}\text { Interval of the Use of Multimedia by } \\
\text { the Students }\end{array}$ & Criteria \\
\hline$X_{i}+1.8 S D_{i}<\bar{x}$ & $46.20<\bar{x}$ & VeryGood \\
$X_{i}-0.6 S D_{i}<\bar{x} \leq X_{i}+1.8 S D_{i}$ & $37.40<\bar{x} 46.20$ & Good \\
$X_{i}-0.6 S D_{i}<\bar{x} \leq X_{i}+0.6 S D_{i}$ & $28.60<\bar{x} \leq 37.40$ & Good Enough \\
$X_{i}-1.8 S D_{i}<\bar{x} \leq X_{i}+0.6 S D_{i}$ & $19.80<\bar{x} 28.60$ & Insufficient \\
$X_{i} \leq X_{i}+1.8 S D_{i}$ & $\bar{x} \leq 19.80$ & Very insufficient \\
\hline
\end{tabular}




\section{Results and Analysis}

In this development study, a design for developing instructional multimedia for teaching line and angle topics has been developed. The design in this study contains some things, such as 1) basic competencies and learning indicators that are going to be achieved; 2) materials to be learned; 3) description of activities in each page; 4) components in each page; 5) layout of each page and; 6) flowchart.

This study has successfully developed a product of instructional multimedia for teaching line and angle to the seventh-grade students of the junior high school. What follows is a brief explanation of the layout in the multimedia developed. at the time the multimedia is run, an initial layout will emerge from the multimedia like what is shown in Figure 1. With the layout of the multimedia as shown in Figure 1, the multimedia has a flexible navigation. The student can see the competencies that he or she has to achieve by selecting SK/KD button. If the student presses the button Klik disini, a page will appear that presents video selection menu for implementing line and angle concepts. For instance, the student selects the application video in the airline, the display is shown in Figure 2.

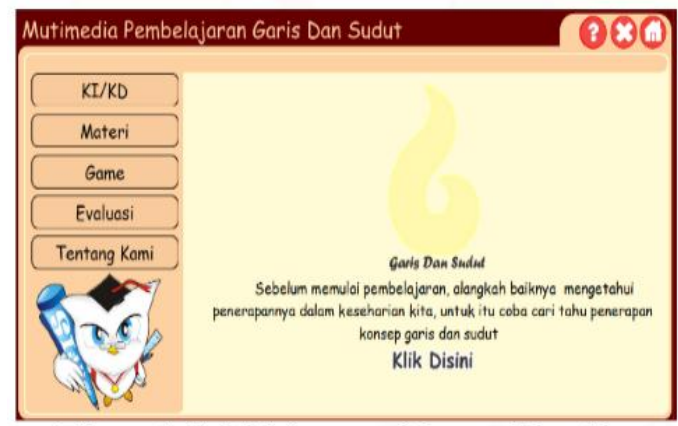

Figure 1. Initial layout of the multimedia

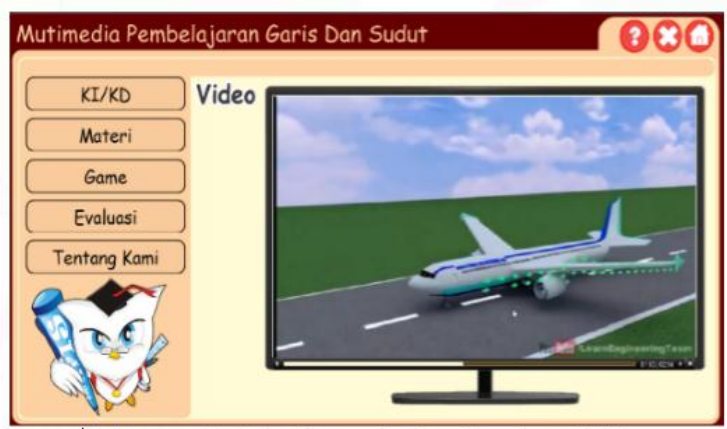

| Figure 2 Display of Application Video

In the multimedia, the students can see games, a set of problems, and the developers' profiles, by selecting a button in the multimedia layout. When the student selects student evaluation button, he or she will be directed to two sets of problems, i.e., objective problems that contain problems about the line and angle and problems on materials on the geometrical element. The multimedia presents a game of billiards which has been designed in such a way to accomplish a mission and to win the game, using the concepts of line and angle. The display of the game can be seen in Figure 3.

When a student selects the material button, some material choices are displayed, the presentations of the materials are almost the same. At the initial stage the students are given an illustration in the form of pictures related to the material, then on the next page, the student will be given problems, to help in finding concepts of a particular material.If the student does not know the material, he or she can see the illustration of the material which is presented in an instructional media. However, when he or she has understood it, on the following page he or she will be given a comprehension test, the display of each of the pages can be seen in Figures 4,5, and 6.

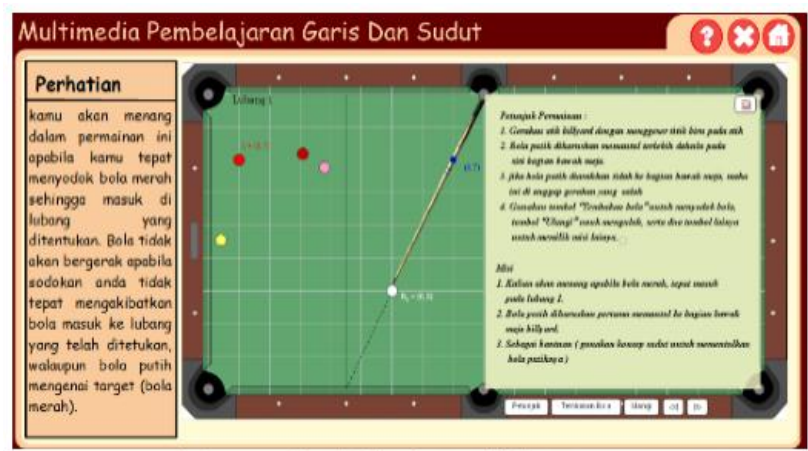

Figure 3. Display of the game

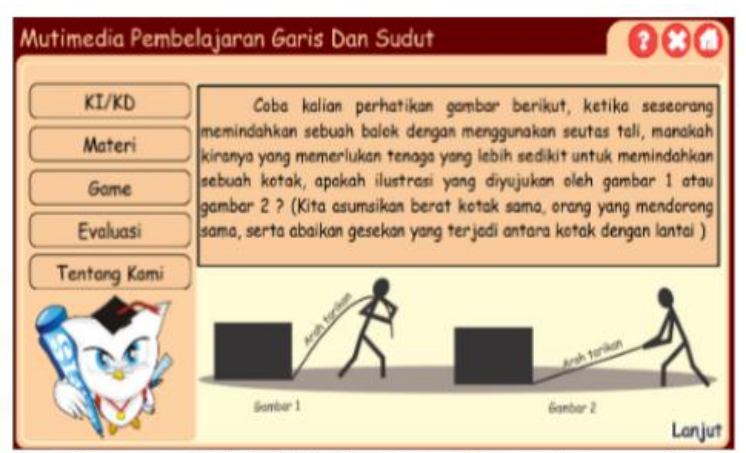

Figure 4. Initial Display of a submaterial 


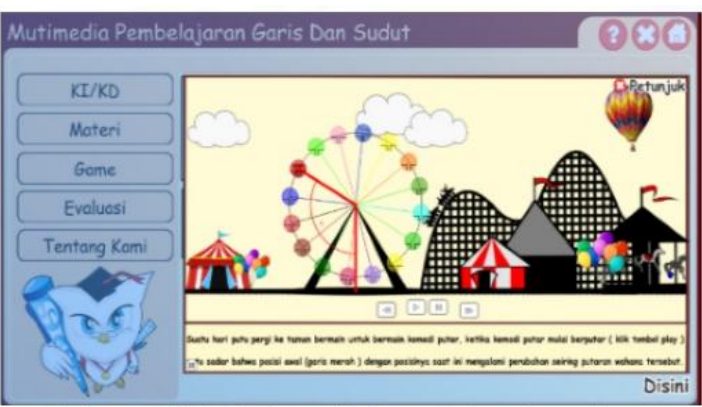

Figure 5. Display of instructional media

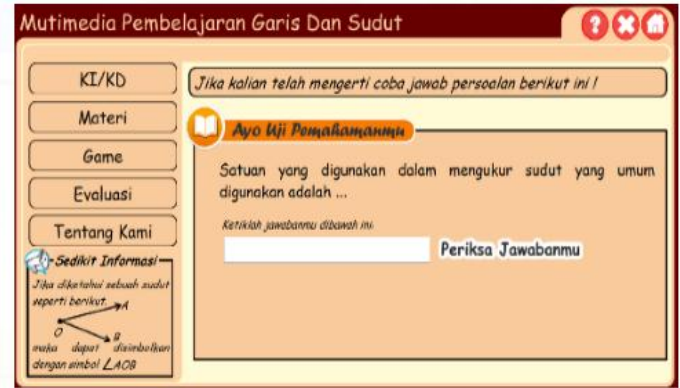

Figure 6. Display of a comprehension test

In various sub-materials, the student is given a problem in the form of short completion to test his or her deeper understanding. Different from the problems in the comprehension test, which only present a consequence of the student's answers, whether the student is wrong or right in answering the problems given, the problems on the conclusion page contain feedbacks when the student fails to answer the problems, so that he or she is directed to find the answers by clicking the button Cari Tahu jawabanya to help him or her to find the answers to the problems that he or she could not answer correctly. To get clearer information, see the conclusion in Figure 7.

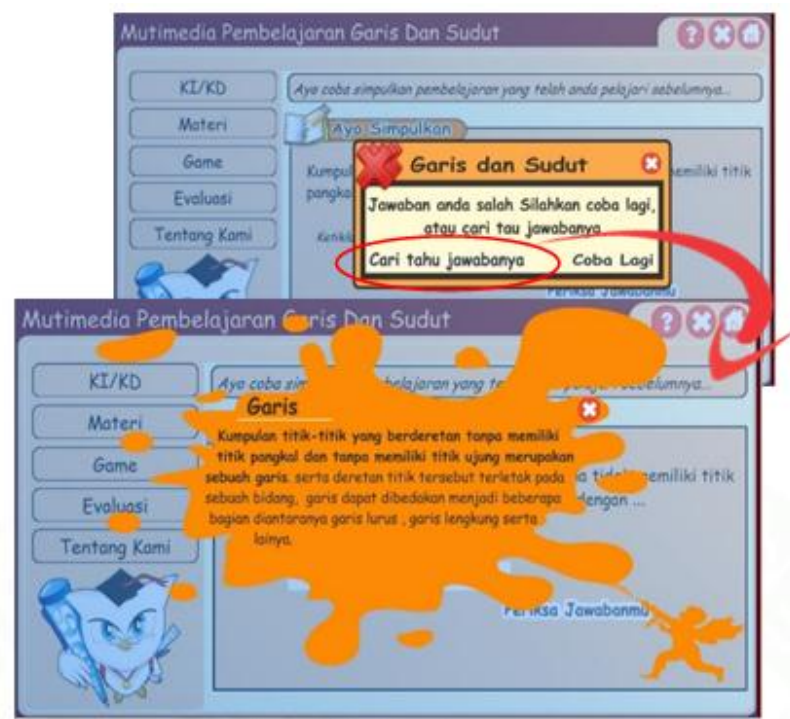

Figure 7. Conclusion page

The validation of the instructional multimedia for line and angle was done by instructional material experts by filling in a validation questionnaire. The recaps of the result of validation of the instructional multimedia for teaching line and angle at the first stage by each expert is shown in Table 4 and Table 5.

Table 4

Recap of Result of Validation of Instructional Multimedia by Instructional Material Experts

\begin{tabular}{ll}
\hline Expert I's Total Score & 45 \\
Expert II Total Score & 42 \\
Average Score & 43.5 \\
Criterion & Valid \\
\hline
\end{tabular}


Table 5

Recap of Result of Validation of Instructional Multimedia by Material Experts

\begin{tabular}{ll}
\hline Expert I's Total Score & 17 \\
Expert II Total Score & 17 \\
Average Score & 17 \\
Criterion & Valid \\
\hline
\end{tabular}

Based on the result of validation from instructional material experts and material experts in Table 4 and Table 5 it is clear that the instructional multimedia developed belongs to valid criterion since it meets the valid criterion from instructional material and material experts. Viewed from the validation by the experts through questionnaires that they filled in, the instructional multimedia, in general, can be easily managed and its operation is very simple and can be operated in any computer or laptop without a complex installation and without any need for installing other applications. In addition, if it is viewed from the visual communication aspect, the multimedia developed has been communicative, has flexible navigation, easy to operate, and from the presentation aspect, and audio aspect it is good and interesting.

The materials presented in the multimedia, in general, have matched the competencies that are desired to be achieved, the presentation of the materials is already contextual, and has been organized systematically, logically and clearly. The contents of the multimedia have helped in the learning process. The evaluation of the multimedia in terms of materials did not increase, from the first stage to the second stage,i.e., it remained as shown in Table 5. In addition to the evaluation of the multimedia validity, the student response to the multimedia is also very good, as indicated by the average score from the student questionnaire 47.63 , which increased from 46.60 at the first stage.

This result agrees with what Rani Kristina Dewi (2011) and Amalia Ima Nurjayanti (2015), in which it was found that the interactive instructional multimedia is liable to be developed to help students especially in the teaching of mathematics

\section{Conclusion}

Based on the result of data analysis and discussion it can be concluded as follows.

1) The design of the instructional multimedia for teaching line and angle in this study is simple, clear, and contains, among other things, 1) basic competencies and learning indicators to be achieved in the teaching by using the multimedia developed; 2) material items to be learned; 3) description of activities for each page; 4) components contained in each page; 5) layout design of each page and 6) flowchart.

2) The design of the instructional multimedia for teaching line and angle has been implemented by using GeoGebra as an application for developing exploration media, Camtasia Studio as the application for editing video, Lectora Inspire as the application for making layouts and quiz in multimedia. Thus the implementation that has been done has produced an instructional multimedia for teaching line and angle for the $7^{\text {th }}$-grade students of junior high school which is presented $\mathrm{n}$ CD form.

3) The instructional multimedia the has been developed has been validated. The result of validation shows that it has met the valid criterion so that it can be accepted and viable as the instructional media for line and angle topics.

It is suggested that teachers use the instructional multimedia developed to support IT-based instruction so that it can increase the students' interest in learning. And other researchers who are interested to continue this research can develop instructional multimedia for the topic of drawing angles so that in the process of learning the students who usually do not bring tools for drawing angles can be equipped directly in the instructional media. In addition, the researchers who are interested can also develop instructional media or an educational game which can be operated or played in a smartphone.

\section{Acknowledgements}

The authors wish to thank all parties whose support and contribution has made this article possible. In particular, the first author would like to extend his appreciation and gratitude to the second and third authors for their constant support and motivation. 


\section{References}

Asyhar, R. (2012). Kreatif mengembangkan media pembelajaran.

Azhar, A. (2005). Multimedia Pembelajaran (6th ed.). Jakarta: PT. Raja Grafindo Persada.

Astawa, I. N., Handayani, N. D., Mantra, I. B. N., \& Wardana, I. K. (2017). Writing English Language Test Items as a Learning Device: A Principle of Habit Formation Rules. International Journal of Social Sciences and Humanities (IJSSH), 1(3), 135-144.

Amalia Ima, N. (2015). Pengembangan Multimedia Pembelajaran Matematika Berbasis Android Untuk Siswa Kelas 3 Sekolah Dasar (Doctoral dissertation, Universitas Negeri Yogyakarta).

Ambarwati, D. S. (2013). Peningkatan Hasil Belajar Matematika Melalui Penerapan Pembelajaran Matematika Realistik pada Siswa Kelas 2 SD Negeri 2 Sidoharjo Kecamatan Sruweng Kabupaten Kebumen Semester II Tahun Pelajaran 2012/2013 (Doctoral dissertation, Program Studi Pendidikan Guru Sekolah Dasar PSKGDJ FKIP-UKSW).

Dewi, R. K. (2011). Pengembangan Multimedia Pembelajaran Matematika "Math-Tainment" Materi Pokok Garis dan Sudut untuk SMP Kelas VII (Doctoral dissertation, UNY).

Musfiqon, H. M. (2012). Pengembangan media dan sumber pembelajaran. Jakarta: Prestasi Pustaka.

Permendiknas nomor 16 tahun. (2007). Peraturan Menteri Pendidikan Nasional Republik Indonesia (pp. 1-32). https://doi.org/10.1017/CBO9781107415324.004

Suryasa, I. W., Prayoga, I. G. P. A., \& Werdistira, I. W. A. (2017). An Analysis of Students' Motivation Toward English Learning As Second Language Among Students In Pritchard English Academy (PEACE). International Journal of Social Sciences and Humanities (IJSSH), 1(2), 43-50.

Maba, W., Perdata, I. B. K., \& Astawa, I. N. (2017). Constructing Assessment Instrument Models for Teacher's Performance, Welfare and Education Quality. International Journal of Social Sciences and Humanities (IJSSH), $1(3), 88-96$.

Widura, S. (2010). Be An Absolute Genius: Panduan Praktis Learn How To Learn Sesuai Cara Kerja Alami Otak. Jakarta: PT Elex Media Komputindo. 